\title{
Hemşirelik Öğrencilerinin ve Hemşirelerin Bakıma iliş̧kin Tutum ve Davranışları
}

\author{
Birgül Cerit $^{1} \odot$, Nevin Çıtak Bilgin ${ }^{1} \oplus$, Simge Çoşkun ${ }^{1} \odot$, Songül Yorgun ${ }^{2} \odot$
}

'Bolu Abant İzzet Baysal Üniversitesi, Sağlık Bilimleri Fakültesi, Hemşirelik Bölümü, Bolu, Türkiye 2il Sağlık Müdürlüğü, Bolu İzzet Baysal Devlet Hastanesi, Sağlık Bakım Hizmetleri, Bolu, Türkiye

Birgül Cerit, Doç. Dr. Nevin Çıtak Bilgin, Dr. Öğr. Üyesi Simge Çoşkun, Dr. Songül Yorgun, Hemşire
Iletişim:

Doç. Dr. Birgül Cerit

Bolu Abant Izzet Baysal Üniversitesi, Sağlık Bilimleri Fakültesi, Hemşirelik Bölümü, Bolu, Türkiye

Tel: +903742544773

E-Posta: birgulcerit@yahoo.com.tr

\section{ÖZET}

Amaç: Bu araştırma, hemşirelik öğrencileri ve hemşirelerin hemşirelik bakımına ilişkin tutum ve davranışlarııı belirlemek amacıyla gerçekleştirilmiştir.

Yöntem: Araştırma tanımlayıcı olarak yapıımıştır. Veriler araştırmaya katılmaya gönüllü olan, bir üniversite hastanesinde görev yapan 101 hemşire ve bir sağlık yüksekokulunda okuyan 227 hemşirelik öğrencisinden elde edilmiştir. Araştırma verileri kişisel bilgi formu ve Bakım Odakı Hemşire-Hasta Etkileşimi Ölçeği kullanılarak toplanmışıı. Verilerin analizinde tanımlayııı istatistikler, Bağımsız İi Örnek t-Testi, Tek Yönlü Varyans Analizi, Mann-Whitney U Testi ve Kruskal Wallis H Testi kullanıımııstır.

Bulgular: Hemşirelerin bakım odaklı hemşire hasta etkileşimi ölç̧̌̆i önemlilik, yeterlilik ve uygulanabilirlik boyutu puan ortalaması sırasılla $299.33 \pm 38.65 ; 284.56 \pm 38.94 ; 267.73 \pm 50.21$ 'dir. Hemşirelik öğrencilerinin bakım odakı hemşire hasta etkileşimi ölçeği önemlilik, yeterlilik ve uygulanabilirlik boyutu puan ortalaması sırasılla $314.92 \pm 37.28 ; 276.78 \pm 40.40 ; 277.81 \pm 47.09$ 'dir. Hemşirelik öğrencileri ve hemşirelerin önemlilik boyutu puan ortalamaları arasında anlamlı bir fark olduğu belirlenmiştir $(p<.05)$. Hemşirelik öğrencilerinin cinsiyete göre bakım odaklı hemşire-hasta etkileşimi ölçeği puan ortalamaları arasında anlamlı fark belirlenmemiş olup ( $p>.05)$, sınıf düzeyine göre ise önemlilik ve uygulanabilirlik boyutları toplam puan ortalamaları arasında anlamlı bir fark tespit edilmiștir $(p<.05)$. Hemşirelerin cinsiyet, eğitim düzeyi ve mesleki kıdemine göre bakım odaklı hemşire-hasta etkileşimi ölç̧eği puan ortalamaları arasında anlamlı fark bulunamamıştır $(p>.05)$.

Sonuç: Araştırma sonucunda, hemşire ve öğrenci hemşirelerin bakım odaklı hemşire hasta etkileşimine yönelik tutum ve algılarının olumlu yönde olduğu, öğrenci hemşirelerin bakım odaklı hasta-hemşire ilişkisini hemşirelere göre daha önemli olarak algıladıkları saptanmıştır.

Anahtar sözcükler: Hemşire-hasta etkileşimi, hemşire, ögrenci hemşire, iletişim

\section{ATTITUDES AND BEHAVIORS OF NURSES AND STUDENT NURSES REGARDING CARE}

\section{ABSTRACT}

Aim: This study was conducted to determine the attitudes and behaviors of nurses and student nurses regarding nursing care.

Method: A descriptive model was used in the study. The data were obtained from 101 nurses working in a university hospital and 227 nursing students studying in a health school, who volunteered to participate in the research. Research data were collected using a personal information form and the Caring Nurse-Patient Interaction Scale. Descriptive statistics, Independent Samples T-Test, One Way Anova, Mann-Whitney U Test and Kruskal Wallis H-Test were used in the data analysis.

Results: The nurses' mean scores from the "importance", "competence" and "feasibility" subscales of the caring nurse-patient interaction scale were $299.33 \pm 38.65,284.56 \pm 38.94$, and $267.73 \pm 50.21$, respectively. The student nurses' mean scores from the "importance", "competence" and "feasibility" subscales of the caring nurse-patient interaction scale were $314.92 \pm 37.28$, $276.78 \pm 40.40$, and $277.81 \pm 47.09$, respectively. It was determined that there was a statistically significant difference between the mean scores of the importance subscale of nursing students and nurses $(p<.05)$. There was no significant difference between nursing students' average of caring nurse-patient interaction scale scores according to gender $(p>.05)$. Significant differences were found between the mean of the total scores of importance and competence dimensions by class level $(p<.05)$. In addition, no significant difference was found between nurses' average of caring nurse-patient interaction scale scores according to gender, education level and working duration $(p>.05)$.

Conclusion: It was determined that the attitudes and perceptions of nurses and student nurses regarding caring nurse-patient interaction were positive and that student nurses perceived the caring nurse-patient relationship as more important when compared to the perceptions of nurses.

Keywords: Nurse-patient interaction, nurse, nursing student, communication
Gönderilme Tarihi : 06 Nisan 2018

Revizyon Tarihi : 23 Mayıs 2018

Kabul Tarihi : 26 Mayıs 2018 
$\mathrm{H}$ emşirelik insana temellenen ve esas rolü bakım olan bir meslektir $(1,2)$. Bakım ise, 'insanların temel ihtiyaçlarını karşılamalarına, yeteneklerini geliştirme ve sürdürmelerine, hayatta kalabilmek ve en azından asgari düzeyde işlev görebilmek için mümkün olduğunca acıdan uzak yaşayabilmelerine yardım etmek üzere özenle ve saygılı bir şekilde doğrudan yapılan her şeydir (3). Hemşirelik için bakım; özgün ve vazgeçilmez bir kavramdır (1). Hemşirelik bakımının temel amacı, karşılıklı güvene dayalı bir iletişim ve etkileşim içinde hizmet verilen bireyi tanımak, bakım gereksinimlerini belirlemek ve sonuçta bireyin; sorunları ile daha etkin baş edebilir, gereksinimlerini karşılayabilir hale gelmesini sağlamaktır (4). Dolayısıyla bakım en az iki kişi ile başlayan ve gelişen bir etkileşim sürecidir.

Hemşirelik bakımının odağında birey/hasta yer almaktadır. Hemşire hastasına bakım vermeden önce hastası ile birlikte onun gereksinimlerini saptar, fiziksel, psiko-sosyal ve spiritüel yönünü göz önünde bulundurarak bakım eyleminde bulunur (5). Bakımın etkin bir şekilde sunulabilmesi için etkin bir iletişim becerisine gereksinim vardır. Çünkü insanlar ancak iletişim yoluyla bilgi, duygu, düşünce ve sorunlarını paylaşır, kendilerini ve başkalarını mutlu etme olanağı elde eder, sorunlarını çözümler, çevrelerini daha iyi anlar, kontrol eder ve çevrelerinin geliştirilmesine katkıda bulunabilirler (6).

Sağlıkı/hasta birey ile kurulan kişilerarası ilişki, hemşirelerin elindeki önemli bir bakım ve tedavi aracı olmakla birlikte; hastalığın seyri ve sonucunu etkileyen kritik etmenlerden birisidir (4, 7-11). Yapılan çalışmalarda, hemşirelerin etkili kişilerarası ilişkiler ve iletişim becerisi geliştirmesinin, hastaların hizmetten memnuniyetini, iyileşme motivasyonunu, hastalık ve tedaviye uyumunu artırdığı, mental sağlıklarını olumlu yönde etkilediği, depresyon ve anksiyete oranlarını azalttığı saptanmıştır (4, 11-13). Araştırma sonuçlarının da gösterdiği gibi hemşirelik bakımı ile istenilen hasta çıtılarına ulaşabilmede, hemşirelerin profesyonel bilgi ve becerilerini hemşire-hasta ilişkisine yansıtmaları önemlidir $(1,14)$. Bu nedenle hastanın bakımından sorumlu olan hemşirelere iletişime uygun çevrenin oluşturulması ve hasta ile etkili iletişim kurulmasında önemli görevler düşmektedir $(6,11,15)$.

Hemşire-hasta arasında profesyonel olarak gerçekleştirilen bu ilişki öğrencilik yıllarında verilen eğitimle başlamakta ve mesleki yaşantı süresince gelişmektedir. Hemşire-hasta arasında başarılı bir şekilde oluşturulan ve geliştirilen bu etkileşim hemşirelere mesleki yaşantılarında doyum, başarı, üretkenliği getirmekte (6) ve hasta sonuçlarına olumlu yansıyabilmektedir. Bu bağlamda hemşirelerin ve geleceğin meslek üyesi olarak öğrenci hemşirelerin bakım verme süreci içerisinde istendik hemşire-hasta etkileşimini oluşturabilmeleri ve sürdürebilmeleri açısından bakım odaklı hemşire-hasta etkileşimine yönelik tutum ve davranışlarının değerlendirilmesi önemlidir (14). Bu çalışmada hemşirelik öğrencileri ve hemşirelerin bakım uygulamalarında hemşire-hasta etkileşimine yönelik tutum ve davranışlarını değerlendirmek amaçlanmıştır.

\section{Araştırmanın amacı}

$\mathrm{Bu}$ araştırma, hemşirelik öğrencilerinin ve hemşirelerin bakıma yönelik tutum ve davranışlarını belirlemek amacıyla gerçekleştirilmiştir.

\section{Araştırma soruları}

- Hemşirelik öğrencilerinin bakıma ilişkin tutum ve davranışları nedir?

- Hemşirelerin bakıma ilişkin tutum ve davranışları nedir?

- Hemşirelik öğrencilerinin ve hemşirelerin bakıma ilişkin tutum ve davranışları arasında fark var mıdır?

- Hemşirelik öğrencilerinin cinsiyet ve sınıf düzeyine göre bakıma ilişkin tutum ve davranışları arasında fark var mıdır?

- Hemşirelerin cinsiyet, eğitim düzeyi ve mesleki kıdemine göre bakıma ilişkin tutum ve davranışları arasında fark var mıdır?

\section{Gereç ve yöntem}

Çalışma grubu

Araştırma 1 Mayıs-1 Haziran 2015 tarihleri arasında bir üniversite hastanesinde görev yapan ve çalışmaya katılmaya gönüllü olan 101 hemşire ve bir sağlık yüksekokulunun hemşirelik bölümünde eğitim gören, çalışmaya katılmaya gönüllü olan 227 öğrenci ile gerçekleştirilmiştir.

\section{Veri toplama araçları}

Bu çalışmada hemşire ve hemşirelik öğrencilerinin tanımlayıcı özelliklerine ilişkin bilgilerin toplanmasında Kişisel Bilgi Formu, bakıma ilişkin tutum ve davranışlarını belirlemek için ise Bakım Odaklı Hemşire-Hasta Etkileşimi Ölçeği kullanılmıştır.

Bakım Odaklı Hemşire-Hasta Etkileşimi Ölçeği: Cossette ve ark. (2005) tarafından geliştirilmiş olan 'Bakım Odaklı Hemşire-Hasta Etkileşimi Ölçeği (BOHHEÖ)'nin Türkçe'ye uyarlama çalışması Atar ve Aştı (2012) tarafından yapılmıştır. Bu ölçek 70 madde, 3 boyut (Önemlilik, yeterlilik 
ve uygulanabilirlik) ve 10 alt boyuttan (1.Hümanizm, 2.Umut, 3.Duyarlııı, 4.Yardım edici ilişki, 5. Duyguların ifade edilmesi, 6. Sorun çözme, 7. Öğretim, 8. Çevre, 9. Gereksinimler,10. Maneviyat) oluşan $5^{\prime}$ li likert tipinde bir ölçüm aracıdır. Ölçeğe ilişkin maddeler Hiç (1), Biraz (2), Orta Derece (3), Çok (4), Son Derece (5) olarak derecelendirilmiştir. Her bir boyut için alt boyutlar değişmemekte ve aynı maddelerden elde edilmektedir. Her bir değişken için ölçekten alınabilecek en düşük ve en yüksek olası puan 70-350 arasındadır. Bireylerin ölçeklerden aldıkları puan arttıkça, bakım odaklı hemşire-hasta etkileşimine ilişkin tutum ve davranışları olumlu yönde artmaktadır. Atar ve Aştı (2012)'nın çalışmasında ölçeğin önemlilik boyutu için cronbach alfa katsayısı 0.99, yeterlilik boyutu için 0.98, uygulanabilirlik boyutu için 0.99 belirlenmiştir (2). Bu çalışmada öğrenci grubu için önemlilik, yeterlilik ve uygulanabilirlik boyutu cronbach alfa değeri 0.98 hesaplanmıştır. Hemşire grubunda önemlilik boyutu için cronbach alfa katsayısı 0.95 , yeterlilik için 0.93 ve uygulanabilirlik için ise 0.96 olarak tespit edilmiştir.

\section{Verilerin değerlendirilmesi}

Bu çalışmada kullanılacak istatistiklerin belirlenebilmesi için verilerin normal dağılım gösterip göstermediği çarpıklık (skewness) ve basıklık (kurtosis) değerleri hesaplanarak tespit edilmiştir. Alanyazında verilerin normal dağıım gösterebilmesi için çarpıklık ve basıklık değerlerinin -2 ile +2 arasında değişmesi gerektiği yer almaktadır (16). Buna göre, BOHHEÖ'den elde edilen puanın normallik şartını sağladığı belirlenmiştir (öğrenci= skewness: -0.651 , kurtosis: 0.116 ; hemşire $=$ skewness: -0.821 , kurtosis: 1.809$)$. Bu sonuca dayalı olarak hemşirelik öğrencileri ve hemşirelerin bakıma ilişkin tutum ve davranışları arasında fark olup olmadığını belirlemek için bağımsız iki örnek t-testi kullanılmıştır. Hemşirelik öğrencileri ve hemşirelerin tanımlayıcı özelliklerine ilişkin verilerin değerlendirilmesinde sayı ve yüzde, bakıma ilişkin tutum ve davranışlarının belirlenmesinde ise ortalama ve standart sapma değerlerinden yararlanılmıştır. Hemşirelik öğrencilerinin bakıma ilişkin tutum ve davranışlarının bazı tanımlayıc özellikler açısından karşılaştırılmasında t testi, tek yönlü varyans analizi ve ileri istatistik olarak post hoc (Bonferroni) testi kullanıımışır. Hemşirelerin bakıma ilişkin tutum ve davranışlarının bazı tanımlayıcı özellikler açısından karşılaştırılmasında ise Mann-Whitney $U$ testi ve Kruskal Wallis $\mathrm{H}$ testi kullanılmıştır.

\section{Araştırmanın etik yönü}

Araştırmanın uygulanması için etik kurul izni (protokol no: 2015/116), araştırmanın yapıldığı kurumlardan resmi yazıIı izin, katılımcılardan yazııı aydınlatılmış onam ve araştırmada kullanılan ölçek için yazarından yazııı izin alınmıştır.

\section{Bulgular}

Hemşirelik öğrencileri ve hemşirelerin tanımlayıcı özellikleri için Tablo 1 incelendiğinde, öğrencilerin yaş ortalamasının $20.41 \pm 1.43$ olduğu, \%78.0'ının kadın, \%22.0'sinin erkek olduğu görülmektedir. Öğrencilerin \%33.9'unun 1.sınıf, \% 31.7'sinin 2.sınıf, \% $18.1^{\prime}$ inin 3. sınıf ve \%16.3'ünün ise 4. sınıfta eğitim gördüğü belirlenmiştir. Çalışmaya katılan hemşirelerin yaş ortalamasının $30.00 \pm 6.62$ olduğu, \%95.0'ının kadın ve \% 5.0'ının erkek olduğu, \%58.4'ünün lisans mezunu ve \%40.6'sının ise 1-5 yıllık mesleki deneyime sahip olduğu belirlenmiştir (Tablo 1).

Hemşirelik öğrencileri ve hemşirelerin bakıma ilişkin tutum ve davranışları arasında fark olup olmadığını gösteren bağımsız iki örnek t-testi sonuçları Tablo 2'de verilmiştir. T test analizi sonuçlarına göre, öğrenci hemşirelerin ve hemşirelerin önemlilik boyutu puan ortalamaları arasında anlamlı fark olduğu belirlenmiştir (t:3.455, p: 0.001).

\section{Tablo1. Hemşirelik öğrencileri ve hemşirelerin tanımlayıcı özellikleri}

\begin{tabular}{|c|c|c|}
\hline Hemşirelik öğrencilerinin özellikleri & $N$ & $\%$ \\
\hline $\begin{array}{l}\text { Yaş grubu } \\
18-19 \\
20-22 \\
23-26 \\
\text { Yaş ortalaması (X: } 20.41 \pm 1.43)\end{array}$ & $\begin{array}{c}56 \\
157 \\
14\end{array}$ & $\begin{array}{c}24.7 \\
69.2 \\
6.1\end{array}$ \\
\hline $\begin{array}{l}\text { Cinsiyet } \\
\text { Kadın } \\
\text { Erkek }\end{array}$ & $\begin{array}{c}177 \\
50\end{array}$ & $\begin{array}{l}78.0 \\
22.0\end{array}$ \\
\hline $\begin{array}{l}\text { Sınıf düzeyi } \\
1 \\
2 \\
3 \\
4\end{array}$ & $\begin{array}{l}77 \\
72 \\
41 \\
37\end{array}$ & $\begin{array}{l}33.9 \\
31.7 \\
18.1 \\
16.3\end{array}$ \\
\hline Toplam & 227 & 100.0 \\
\hline Hemşirelerin özellikleri & N & $\%$ \\
\hline $\begin{array}{l}\text { Yaş grubu } \\
18-25 \\
26-33 \\
34+ \\
\text { Yaş ortalaması(X:30.00 } \pm 6.62)\end{array}$ & $\begin{array}{l}30 \\
38 \\
33\end{array}$ & $\begin{array}{l}29.7 \\
37.6 \\
32.7\end{array}$ \\
\hline $\begin{array}{l}\text { Cinsiyet } \\
\text { Kadın } \\
\text { Erkek }\end{array}$ & $\begin{array}{c}96 \\
5\end{array}$ & $\begin{array}{c}95.0 \\
5.0\end{array}$ \\
\hline $\begin{array}{l}\text { Eğitim düzeyi } \\
\text { SML } \\
\text { Önlisans } \\
\text { Lisans } \\
\text { Lisansüstü }\end{array}$ & $\begin{array}{c}24 \\
11 \\
59 \\
7\end{array}$ & $\begin{array}{c}23.8 \\
10.9 \\
58.4 \\
6.9\end{array}$ \\
\hline $\begin{array}{l}\text { Mesleki kıdem } \\
1 \text { yıldan az } \\
1-5 \text { yıl } \\
6-10 \text { yıl } \\
10 \text { yıl ve üzeri }\end{array}$ & $\begin{array}{c}7 \\
41 \\
22 \\
31\end{array}$ & $\begin{array}{c}6.9 \\
40.6 \\
21.8 \\
30.7\end{array}$ \\
\hline Toplam & 101 & 100.0 \\
\hline
\end{tabular}


Aritmetik ortalama değerlerine göre öğrencilerin önemlilik $(314.92 \pm 37.28)$ ve uygulanabilirlik $(277.81 \pm 47.09)$ boyutlarından hemşirelere (sırasıyla, 299.33 \pm 38.65 , 267.73 \pm 50.21) göre daha yüksek puan aldıkları, yeterlilik boyutun-

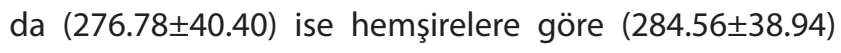
daha düşük puan aldıkları saptanmıştır (Tablo 2).

$\begin{aligned} & \text { Tablo 2. Hemşirelik Öğrencileri ve hemşirelerin Bakım Odakı Hemşire- } \\
& \text { Hasta Etkileşimi Ölçeği boyutlarına ilişkin puan ortalamalarının } \\
& \text { karşılaştırıması }\end{aligned}$
\begin{tabular}{lccccc} 
BOHHEÖ & Öğrenci Hemşire \\
Boyutları & Ort \pm ss & $\begin{array}{c}\text { Hemşire } \\
\text { Ort } \pm \text { ss }\end{array}$ & $\boldsymbol{t}$ & $\boldsymbol{p}$ \\
\hline Önemlilik & $314.92 \pm 37.28$ & $299.33 \pm 38.65$ & 3.455 & $0.001^{*}$ \\
Yeterlilik & $276.78 \pm 40.40$ & $284.56 \pm 38.94$ & 1.629 & 0.104 \\
Uygulanabilirlik & $277.81 \pm 47.09$ & $267.73 \pm 50.21$ & 1.753 & 0.081 \\
\hline${ }^{*} p<0.05$ & & & & &
\end{tabular}

Hemşirelik öğrencileri ve hemşirelerin bakıma ilişkin tutum ve davranışlarının bazı tanımlayıcı özelliklere göre karşılaştırılması Tablo 3'de gösterilmiştir. Buna göre, öğrencilerin cinsiyetleri ile önemlilik (t: .816, p: .416), yeterlilik (t:.352, p: .725) ve uygulanabilirlik (t:-.412, p: .680) boyutları puan ortalamaları arasında anlamlı bir fark saptanmamıştır. Sınıf düzeyi ile önemlilik (F: 3.163, p: .025) ve uygulanabilirlik (F: 5.617, p: .001) boyutları puan ortalamaları arasında istatistiksel olarak anlamlı bir fark bulunmuştur. Farkın hangi ikili gruptan kaynaklandığını gösteren çoklu karşılaştırma testi (Bonferroni testi) sonuçlarına göre, birinci sınıf öğrencileri ile ikinci sınıf öğrencilerinin önemlilik boyutu puan ortalamaları arasında anlamlı bir fark olduğu tespit edilmiştir (p: .018). Uygulanabilirlik boyutuna ilişkin farkın ise birinci-ikinci sınıf (p: .007) ve birinci- üçüncü sınıftan (p: .003) kaynaklandığı belirlenmiştir. Sınıf düzeyi ile yeterlilik (F: 0.906, p: .439) boyutu puan ortalaması arasında ise anlamlı fark saptanmamıştır (Tablo 3).

Hemşirelerin cinsiyet, eğitim düzeyi ve mesleki kıdemleri ile önemlilik, yeterlilik ve uygulanabilirlik boyutu puan ortalamaları arasında istatistiksel açıdan önemli bir fark belirlenmemiştir ( $p>05$ ) (Tablo 3).

\section{Tartışma}

Araştırma bulguları iki başlık altında tartışılmıştır.

Hemşirelik öğrencileri ve hemşirelerin bakıma ilişkin tutum ve davranışları

Araştırmada hemşirelik öğrencilerinin bakım odaklı hemşire-hasta etkileşimlerine yönelik tutum ve davranışlarının olumlu olduğu belirlenmiştir (Tablo 2). Alanyazında yapılan benzer çalışma sonuçları bu araştırma bulgusunu
Tablo 3. Hemşirelik öğrencileri ve hemşirelerde Bakım Odakı HemşireHasta Etkileşimi Ölçeği boyutlarının bazı tanımlayıcı özellikler açısından karşılaştırıması

\begin{tabular}{|c|c|c|c|}
\hline Değişkenler & $\begin{array}{l}\text { Önemlilik } \\
\text { Ort } \pm s s\end{array}$ & $\begin{array}{l}\text { Yeterlilik } \\
\text { Ort } \pm \text { ss }\end{array}$ & $\begin{array}{c}\text { Uygulanabilirlik } \\
\text { Ort } \pm \text { ss }\end{array}$ \\
\hline \multicolumn{4}{|l|}{$\begin{array}{l}\text { Öğrenci } \\
\text { Hemşire }\end{array}$} \\
\hline \multicolumn{4}{|l|}{ Cinsiyet } \\
\hline Erkek & $311.12 \pm 38.02$ & $275.00 \pm 40.83$ & $280.24 \pm 49.01$ \\
\hline $\begin{array}{l}\text { Istatistiksel } \\
\text { Değerlendirme }\end{array}$ & t: . .816, p: .416 & t: .352, p: .725 & t: $-.412, p: .680$ \\
\hline \multicolumn{4}{|l|}{ Sınıf Düzeyi } \\
\hline 2. Sinıf & $305.59 \pm 39.83$ & $271,04 \pm 43.55$ & $270.08 \pm 48.97$ \\
\hline 3. Sinif & $317.65 \pm 39.01$ & $280.46 \pm 38.45$ & $263.87 \pm 45.57$ \\
\hline 4. Sinıf & $311.81 \pm 29.88$ & $275.00 \pm 33.14$ & $273.02 \pm 46.53$ \\
\hline $\begin{array}{l}\text { Istatistiksel } \\
\text { Değerlendirme }\end{array}$ & F: $3.163, p: .025^{\star}$ & F: $0.906, p: .439$ & F: $5.617, p: .001^{*}$ \\
\hline Bonferroni testi & 1. sInIf - 2. sınıf & & $\begin{array}{l}\text { 1. sinif - 2. sinif } \\
\text { 1. sinif - 3. sinif }\end{array}$ \\
\hline \multicolumn{4}{|l|}{ Hemşire } \\
\hline $\begin{array}{l}\text { Cinsiyet } \\
\text { Kadın }\end{array}$ & $299.36 \pm 39.11$ & $284.06 \pm 39.39$ & $266.63 \pm 50.62$ \\
\hline Erkek & $298.80 \pm 31.94$ & $294.20 \pm 30.45$ & $288.80 \pm 39.88$ \\
\hline $\begin{array}{l}\text { Istatistiksel } \\
\text { Değerlendirme }\end{array}$ & U: $217.00, p: .719$ & U:233.00, p: .913 & U: 184.50, p: .385 \\
\hline \multicolumn{4}{|l|}{ Eğitim Düzeyi } \\
\hline SML & $305.66 \pm 30.37$ & $292.75 \pm 34.00$ & $276.08 \pm 55.71$ \\
\hline Önlisans & $305.00 \pm 20.56$ & $291.45 \pm 22.23$ & $279.36 \pm 26.56$ \\
\hline Lisans & $293.45 \pm 44.05$ & $276.47 \pm 41.41$ & $258.79 \pm 50.78$ \\
\hline Lisansüstü & $318.28 \pm 30.36$ & $313.85 \pm 37.91$ & $296.14 \pm 42.07$ \\
\hline $\begin{array}{l}\text { Istatistiksel } \\
\text { Değerlendirme }\end{array}$ & $X^{2}: 3.829, p: .280$ & $X^{2}: 6.053, p: .109$ & $X^{2}: 5.921, p: .116$ \\
\hline \multicolumn{4}{|l|}{ Mesleki Kıdem } \\
\hline 1 yildan az & $272.71 \pm 37.36$ & $270.00 \pm 40.07$ & $253.57 \pm 45.12$ \\
\hline $1-5 \mathrm{yll}$ & $298.90 \pm 39.44$ & $282.26 \pm 47.11$ & $260.78 \pm 61.43$ \\
\hline 6-10 yıl & $292.95 \pm 49.51$ & $278.31 \pm 30.29$ & $263.27 \pm 43.88$ \\
\hline 10 yıl ve üzeri & $310.45 \pm 24.26$ & $295.32 \pm 22.08$ & $283.29 \pm 35.22$ \\
\hline $\begin{array}{l}\text { Istatistiksel } \\
\text { Değerlendirme }\end{array}$ & $X^{2}: 7.585, \mathrm{p}: .055$ & $X^{2}: 5.859, p: .119$ & $X^{2}: 3.658, p: .301$ \\
\hline
\end{tabular}

desteklemektedir $(2,17,18)$. Hemşire-hasta etkileşiminin öğrenilmesi öncelikle eğitim süreci ile gerçekleşmektedir (4). Bu nedenle öğrenci hemşirelerin hem klinik uygulamalarında hem de gelecekte bu mesleği uygularken etkili iletişim kurabilme becerisine sahip olmaları önemlidir. Karaöz (2005)'ün hemşirelik öğrencilerinin bakıma ilişkin algısını değerlendirdiği çalışmasında, öğrenciler 
iyi hemşirelik bakımının iyi iletişime dayandığını ve hastayı bütüncül değerlendirerek gereksinimlerinin uygun şekilde karşılanması gerektiğini vurgulamışlardır (19). Hemşirelik öğrencileri ile yapılan başka bir çalışmada ise, öğrencilerin güven verici iletişimin önemine yönelik algı düzeylerinin yüksek olduğu saptanmıştır (20). Yukarıdaki çalışmaların sonuçları öğrencilerin etkili bakım uygulamalarında iletişimin önemine ilişkin farkındalıklarının olduğunu göstermektedir. Benzer şekilde bu araştırmanın sonuçlarına dayalı olarak, öğrencilerin bakım odaklı hemşire-hasta etkileşimine yönelik olumlu tutum ve davranışlar göstermesi, eğitim sürecinde iletişim becerisini geliştirdiklerini düşündürmektedir. Öğrencilerinin klinik uygulamaları süresince hastalarla iletişim kurmalarının, hasta merkezli çalışmalarının, hemşirelik sürecini etkin kullanmalarının ve müfredatları gereği kişilerarası iletişim dersini almış olmalarının bu olumlu tutuma yansıdığı ifade edilebilir.

Klinik uygulamada görülebilen hemşire-hasta etkileşimine ilişkin tutum ve davranışların tanımlandığı ölçek boyutları değerlendirildiğinde, öğrencilerin yeterlik ve uygulanabilirlik boyutlarına göre önemlilik boyutunda daha olumlu tutum ve davranış sergiledikleri tespit edilmiştir (Tablo 2). Konu ile ilgili yapılan bazı çalışmalar bu çalışmanın sonuçları ile benzerlik göstermektedir $(2,17,18)$. Bazı çalışmalarda ise, hemşirelik öğrencilerinin uygun iletişim becerilerini öğrendikleri ancak kendi iletişim örüntüleri ile bütünleştiremedikleri ve hasta birey ile etkileşimlerine taşımakta güçlükler yaşadıkları belirlenmiştir $(9,21)$. Öğrencilerin, henüz mesleki kimlik oluşturma sürecinde iken, hasta bakımının önemini ve etkin bakım uygulamalarını gerçekleştirmede iletişimin temel rolünü fark etmeleri mesleki gelişim açısından önemlidir. Araştırma sonucunda öğrencilerin bakım odaklı hemşire-hasta etkileşimine ilişkin tutum ve davranışları önemli bulmaları, bu davranışlara ilişkin kendilerini yeterli ve rahat hissetmeleri ve bu tutum ve davranışların uygulanabilir olduğunu düşünmelerinin, hasta merkezli bakımın niteliğine olumlu yansıyabileceği söylenebilir.

Araştırmada hemşirelerin, bakım odaklı hemşire-hasta etkileşimine ilişkin tutum ve davranışlarının olumlu olduğu belirlenmiştir. Hemşirelerin bakıma ilişkin tutum ve davranışları önemli bulma düzeyinin, bu davranışları uygulama konusunda kendilerini yeterli görme ve uygulanabilir olduğunu düşünme durumuna göre daha olumlu olduğu tespit edilmiştir (Tablo 2). Benzer şekilde Bayraktar ve Eşer (2017)'in hemşirelerin bakım odaklı hemşire-hasta etkileşimini değerlendirmek amacıyla yaptıkları çalışmada da bu araştırmanın bulgusuyla örtüşen sonuçlar elde edilmiştir
(14). Bakım hemşirenin en temel sorumluluğudur. Bu sorumluluğun istendik biçimde yerine getirilmesinde etkili iletişim anahtar role sahiptir. Dolayısıyla nitelikli bir bakım, hemşirenin bireylerle etkili iletişim kurabilme yeteneğine bağlıdır $(12,17)$. Sağlıklı/hasta birey ile kurulan kişilerarası ilişki, hemşireler için önemli bir bakım ve tedavi aracı olduğu için hasta memnuniyetini, hastalığın seyrini ve sonucunu etkileyebilmektedir $(4,7-10,13)$.

$\mathrm{Bu}$ çalışmada hemşirelik öğrencilerinin ve hemşirelerin Bakım Odaklı Hemşire-Hasta Etkileşimi Ölçeği boyutlarına ilişkin en yüksek puanı önemlilik boyutundan aldıkları belirlenmiştir. Hemşirelerin bu boyuta ilişkin tutum ve davranışlarının olumlu ancak, puan ortalamalarının öğrencilerden düşük ve aradaki farkın istatistiksel olarak anlamlı olduğu ortaya çıkmıştır (Tablo 2). Konuya ilişkin yapılmış çalışmalarda, hemşirelerin özellikle ilerleyen yıllarda aşırı hasta yoğunluğu ve yoğun çalışma şartları nedeniyle mesleki doyumsuzluk yaşadıkları ve iletişim becerilerini göz ardı edebildikleri belirtilmektedir. $(11,22)$. Bununla birlikte bir başka çalışmada hemşirelerin hasta ile çok kısa süreli olsa dahi olumlu etkileşimde bulunmasının hasta memnuniyetini artırdığı, ancak çoğu zaman hemşirelerin bu etkileşimin sonuçlarına ilişkin farkındalıklarının olmadığı ortaya çıkmışır (10). Dolayısıyla alanyazınla uyumlu olarak bu çalışmada hemşirelerin önemlilik boyutuna ilişkin puan ortalamalarının öğrencilere göre daha düşük olmasının beklendik olduğu ifade edilebilir.

Hemşirelik öğrencileri ve hemşirelerin bazı tanımlayıcı özellikleri ile bakıma ilişkin tutum ve davranışlarının karşılaştırılması

Araştırmada kız öğrencilerin önemlilik ve yeterlilik boyutlarında erkek öğrencilerden daha yüksek puan aldıkları, uygulanabilirlik boyutunda ise erkek öğrencilerin kızlardan daha yüksek puan aldıkları belirlenmiş olup, ancak bu fark istatistiksel açıdan anlamlı bulunmamıştır (Tablo 3). Cossette ve ark (2005)'nın bakım açısından hemşirehasta etkileşimini değerlendirdikleri çalışmada araştırma bulgumuza benzer şekilde cinsiyet ile uygulanabilirlik boyutu puan ortalaması arasında istatstiksel açıdan anlamlı bir fark saptanmamıştır (23). Yine aynı çalışmada önemlilik boyutunun on alt boyutundan sadece birinde, yeterlilik boyutunda da beş alt boyutta cinsiyete göre hemşirehasta etkileşimine ilişkin tutum ve davranışlardaki farklılıklar istatistiksel açıdan anlamlı olarak belirlenmiştir (23). Zaybak ve ark. (2014)'nın hemşirelik öğrencilerinin bakım odaklı hemşire-hasta etkileşimine yönelik tutum ve davranışlarını değerlendirdiği çalışmada, araştırma bulgumuzdan farklı olarak kız öğrencilerin önemlilik ve yeterlilik boyutları puan ortalamaları erkek öğrencilerden anamlı 
düzeyde olumlu belirlenmiştir (18). Geçmişte hemşirelik mesleğine ilişkin toplumsal algı değerlendirildiğinde, daha çok bakım verici rolünden dolayı kadına yakıştırılan bir meslek olarak kabul görürken günümüzde bu mesleği tercih eden erkek öğrenci sayısı her geçen yıl artış göstermektedir (24). Bununla birlikte erkek hemşirelerin toplumda kabul görme oranı artmakta ve hemşirelik mesleğindeki cinsiyetçi yaklaşım da azalmaktadır $(25,26)$.

Araştırmada öğrencilerin sınıf düzeyi ile önemlilik ve uygulanabilirlik boyutları puan ortalamaları arasında istatistiksel olarak anlamlı bir fark bulunmuş olup yeterlilik boyutu puan ortalaması arasında ise anlamlı fark belirlenmemiştir (Tablo 3). Aritmetik ortalama değerlerine dayalı olarak, birinci sınıf öğrencilerinin ikinci sınıf öğrencilerinden daha fazla bakım odaklı hemşire-hasta etkileşimine ilişkin tutum ve davranışları önemli gördüğü, birinci sınıfların ikinci ve üçüncü sınıflardan daha yüksek oranda bu tutum ve davranışları uygulanabilir bulduğu söylenebilir. Zaybak ve ark. (2014)'nın çalışmasında araştırma bulgumuzun aksine sınıf düzeyi ile bakıma ilişkin tutum ve davranışlar arasında istatistiksel açıdan önemli bir fark saptanmamıştır (18). Kalender ve ark (2016)'nın hemşirelik öğrencilerinin bakım odaklı hemşire hasta etkileşimine yönelik tutum ve davranışlarını değerlendirdikleri çalışmada ise ikinci sınıf öğrencilerinin yeterlilik düzeyi puan ortalamaları diğer sınıflardan anlamlı derecede yüksek belirlenmiştir (17). Araştırma bulgumuza dayalı olarak birinci sınıf öğrencilerinin araştırmanın uygulandığı dönemde kişilerarası ilişkiler dersini almakta olmaları ve hemşire-hasta iletişimine ilişkin teorik bilgiyi yeni kazanmış olmalarının hemşire-hasta etkileşimindeki tutum ve davranışlarını etkilediği düşünülmektedir. Bununla birlikte birinci sınıf öğrencilerinin klinik deneyimlerinin daha az olması, klinik ortamda hemşire sayısındaki yetersizlik ve iş yükünün yoğunluğuna ilişkin farkındalıklarının düşük olması nedeniyle, hemşire-hasta etkileşimindeki tutum ve davranışları daha uygulanabilir buldukları söylenebilir.

Araştırmada cinsiyete göre hemşirelerin bakım odaklı hemşire-hasta etkileşimi puan ortalamaları arasında anlamlı bir fark elde edilmemiştir (Tablo 3). Ancak erkek ve kadın hemşirelerin bakım odaklı hemşire-hasta etkileşimine ilişkin tutum ve davranışları önemli bulma, bu konuda kendilerini yeterli hissetme ve uygulanabilir olduğunu düşünme durumlarının olumlu olması, hemşirelik bakımına ilişkin uygulamalarda hemşire-hasta etkileşiminde cinsiyet ayrımı gözetilmeksizin yaklaşım sergilenmesi ve bakımın niteliğinin daha ön planda tutulduğunu göstermesi bakımından önemlidir.
Çalışmada hemşirelerin eğitim düzeyine göre bakım odaklı hemşire-hasta etkileşimi puan ortalamaları arasında anlamlı fark saptanmamıştır (Tablo 3). Benzer şekilde Bayraktar ve Eşer (2017)'in yaptığı çalışmada araştırma bulgumuzdan farklı olarak eğitim düzeyi yüksek olan hemşirelerin bakım odaklı hemşire-hasta etkileşiminin uygulanabilir olduğunu düşündükleri belirlenmiştir. Hemşirelerin iletişim becerilerinin değerlendirildiği diğer çalışmalarda da araştırma bulgumuzun aksine hemşirelerin eğitim düzeyi yükseldikçe iletişim becerilerinin anlamlı düzeyde arttığı bulunmuştur $(27,28)$. Bakıma ilişkin uygulamaların gerçekleştirilmesinde hemşire-hasta etkileşimi önemlidir. Kişilerarası etkileşimin temelini oluşturan en önemli unsur ise iletişim becerisine sahip olabilmektir (29). Hemşirelikte iletişim becerilerinin öğrenilmesi öncelikle eğitim sürecinde gerçekleşmektedir (4). Bu doğrultuda araştırma sonucuna dayalı olarak hemşirelerin eğitim süreçlerinde bakım odaklı hemşire-hasta etkileşimine ilişkin tutum ve davranışlarını olumlu yönde etkileyecek düzenlemelerin yapılmasına gereksinim olduğu söylenebilir.

Çalışmada hemşirelerin mesleki kıdemlerine göre bakım odaklı hemşire hasta etkileşimine ilişkin tutum ve davranışları arasında anlamlı bir fark tespit edilmemiştir (Tablo 3). Araştırma bulgumuzun aksine Bayraktar ve Eşer (2017)'in çalışmasında mesleki kıdeme göre önemlilik ve yeterlilik boyutları puan ortalamaları arasında istatistiksel olarak önemli bir fark olduğu bulunmuştur. Hemşirelerin iletişim becerilerinin incelendiği diğer çalışmaların sonuçları da araştırma bulgumuzdan farklı olarak mesleki kıdeme göre iletişim becerileri arasında istatistiksel olarak önemli fark olduğunu göstermektedir $(29,30)$. Çalışma süresi birçok mesleki deneyimin kazanılmasına ve becerilerin gelişmesine olanak tanımaktadır. Ancak araştırma bulgumuz hemşire-hasta etkileşimine ilişkin tutum ve davranışların olumlu yönde gelişiminde sadece mesleki kıdemin etkili olmadığını göstermektedir.

\section{Sonuç ve öneriler}

Araştırma sonucunda hemşire ve öğrenci hemşirelerin bakım odaklı hemşire hasta etkileşimine yönelik tutum ve davranışlarının olumlu olduğu, öğrenci hemşirelerin bakıma ilişkin tutum ve davranışları hemşirelere göre daha önemli buldukları ve bu farkın istatistiksel olarak anlamlı olduğu ortaya çıkmıştır. Öğrencilerin bakıma ilişkin tutum ve davranışları uygulama konusundaki yeterlikleri, hemşirelerin ise bu tutum ve davranışları uygulanabilir bulma durumu diğer boyutlardan düşük belirlenmiştir. Hemşirelik öğrencilerinin cinsiyete göre bakım odaklı hemşire-hasta etkileşimine ilişkin puan ortalamaları arasında anlamlı fark 
olmadığı, sınıf düzeyine göre ise önemlilik ve uygulanabilirlik boyutları puan ortalamaları arasında istatistiksel olarak anlamlı fark olduğu bulunmuştur. Hemşirelerin ise cinsiyet, eğitim düzeyi ve mesleki kıdemine göre bakım odaklı hemşire-hasta etkileşimine yönelik tutum ve davranışları istatistiksel açıdan önemli fark yaratmamıştır. Araştırma sonuçlarına dayalı olarak hemşirelik eğitim programlarının öğrencilere, hemşire-hasta etkileşiminde uygun tutum ve davranışları sergileyebilmelerine yönelik

\section{Kaynaklar}

1. Dinç L. Bakım Kavramı ve Ahlaki Boyutu. Hacettepe Üniv Sağlık Bilim Fak Hem Derg 2010;74-82. Erişim: http://www. hacettepehemsirelikdergisi.org/pdf/pdf_HHD_105.pdf

2. Yalçın Atar N, Atabek Aştı T. Bakım Odaklı Hemşire-Hasta Etkileşimi Ölçeğinin Güvenirlik ve Geçerliği. IÜFN Hem Derg 2012;20:129-39. Erişim: https://dergipark.org.tr/download/article-file/95107

3. Engster D. Rethinking Care Theory: The Practice of Caring and The Obligation to Care. Hypatia 2005;20:50-74. [CrossRef]

4. Tutuk A, AI D, Doğan S. Hemşirelik Öğrencilerinin İletişim Becerisi ve Empati Düzeylerinin Belirlenmesi. CÜ Hem YO Derg 2002;6:36-41. Erişim: http://eskidergi.cumhuriyet.edu.tr/makale/608.pdf

5. Göçmen Baykara Z. Hemşirelik Bakımı Kavramı. Türkiye Biyoetik Derg 2014;1:92-9.

6. Uyer G. Hemşire Hasta İletişimi ve İletişimin Hasta Yönünden Önemi. Türkiye Klinikleri Tıp Etiği 2000;8:88-94.

7. Caris-Verhallen W, Timmermans L, van Dulmen S. Observation of Nurse-Patient Interaction in Oncology: Review of Assessment Instruments. Patient Educ Couns 2004;54:307-20. [CrossRef]

8. Dearing KS. Getting It, Together: How The Nurse-Patient Relationship Influences Treatment Compliance for Patients with Schizophrenia. Arch Psychiatr Nurs 2004;18:155-63. [CrossRef]

9. Shattell M. Nurse-Patient Interaction: A Review of The Literature. J Clin Nurs 2004;13:714-22. [CrossRef]

10. Zrinyi M, Horvath T. Impact of Satisfaction, Nurse-Patient Interactions and Perceived Benefits on Health Behaviors Following a Cardiac Event. Eur J Cardiovasc Nurs 2003;2:159-66. [CrossRef]

11. Babadağlı B, Ekiz Erim S, Erdoğan S. Hekimlerin ve Hemşirelerin Hastayla Illetişim Becerilerinin Değerlendirilmesi. Fırat Sağlık Hiz Derg 2006;1:52-69.

12. Mccance T, Salter P, Mccormack B. Using The Caring Dimensions Inventory As an Indicator of a Person Centered Nursing. J Clin Nurs 2008;18:409-17. [CrossRef]

13. Haugan G, Innstrand ST, Moksnes UK. The Effect of Nurse-Patient Interaction on Anxiety and Depression in Cognitively Intact Nursing Home Patients. J Clin Nurs 2013;22:2192-205. [CrossRef]

14. Bayraktar D, Eşer İ. Hemşirelerin Bakım Odaklı Hemşire-Hasta Etkileşimine Yönelik Tutum ve Davranışları. J Anat Nurs Health Sci 2017;20:188-94. Erişim: http://e-dergi.atauni.edu.tr/ataunihem/ article/view/5000213785/5000182945

15. Fleischer S, Berg A, Zimmermann M, Wüste K, Behrens J. NursePatient Interaction and Communication: A Systematic Literature Review. J Public Health 2009;17:339-53. [CrossRef]

16. Şencan H. Sosyal ve Davranışsal Ölçümlerde Güvenilirlik ve Geçerlilik, 1. baskı. Ankara: Seçkin Yayıncılık; 2005. ss.200-1. kendilerini yeterli ve rahat hissedebilmeleri için uygun öğrenim yaşantıları sunacak şekilde düzenlenmesi ve klinik uygulamalarda öğrencilerin iletişim becerileri yönünden desteklenmesi önemlidir. Çalışma ortamında ise, hemşire-hasta oranlarının uygun şekilde düzenlenmesi, hemşirenin bakım uygulamalarında hemşire-hasta iletişimini uygun şekilde kullanabileceği zamanın planlanması ve iletişim becerilerinin etkin kullanılmasına ilişkin eğitim programlarının düzenlenmesi önerilebilir.

17. Kalender N, Tosun N, Çınar Fi, Bağçivan G, Yaşar Z. Hemşirelik Yüksekokulu Öğrencilerinin Bakım Odaklı Hemşire-Hasta Etkileşimine Yönelik Tutum ve Davranışlarının Değerlendirilmesi. Gülhane Tıp Derg 2016;58:277-81. [CrossRef]

18. Zaybak A,Günay İsmailoğlu E, Efteli E. Hemşirelik Öğrencilerinin Bakım Odaklı Hemşire-Hasta Etkileşimine Yönelik Tutum ve Davranışları. Uluslararası Hakemli Hem Araş Derg (UHD) 2014;1:2437. [CrossRef]

19. Karaöz S. Turkish Nursing Students' Perception of Caring. Nurse Educ Today 2005;25:31-40. [CrossRef]

20. Birimoğlu C, Ayaz S. Hemşirelik Öğrencilerinin Bakım Davranışlarını Algılamaları. Hacettepe Üniv Hem Fak Dergi 2015;2:40-8. Erişim: http://dergipark.ulakbim.gov.tr/hunhemsire/article/ view/5000188192/5000165545

21. Jones L, Woodhouse D, Rowe J. Effective Nurse Parent Communication: A Study Of Parents' Perceptions in The NICU Environment. Patient Educ Couns 2007;69:206-12. [CrossRef]

22. Tiryaki Şen H, Taşkın Yılmaz F, Pekşen Ünüvar Ö. Hizmet İçi Eğitim Hemşirelerinin İletişim Beceri Düzeyleri. Psikiyatri Hem Derg 2013;4:13-20. [CrossRef]

23. Cossette S, Caraa C, Ricarda N, Pepin J. Assessing Nurse-Patient Interactions from a Caring Perspective: Report of The Development and Preliminary Psychometric Testing of the Caring Nurse-Patient Interactions Scale. Int J Nurs Stud 2005;42:673-86. [CrossRef]

24. Gönç T. Hemşireliğin Geleceği Mesleğin Cinsiyetsizleşmesini Vadediyor Mu? Erkek ve Kadın Hemşirelik Öğrencilerinin Meslek ve Toplumsal Cinsiyeti İlişkilendirme Eğilimlerinin Sosyolojik Analizi. Fe Dergi: Feminist Eleştiri 2016;8:144-67. [CrossRef]

25. Arslan A, Ağaçdiken Alkan S. Üniversite Öğrencilerinde Erkek Hemşire Algısı. Samsun Sağlık Bilim Derg 2016;1. Erişim: https:// dergipark.org.tr/download/article-file/717759

26. Kaya N, Turan N, Öztürk A. Türkiye'de Erkek Hemşire İmgesi. Uluslararası İnsan Bilim Derg 2011;8:16-30. Erişim: http://www. acarindex.com/dosyalar/makale/acarindex-1423936438.pdf

27. Akgün Şahin Z, Kardaş Özdemir F. Hemşirelerin İletişim ve Empat Beceri Düzeylerinin Belirlenmesi. GOP Taksim Eğ Araş Hast JAREN 2015;1:1-7. [CrossRef]

28. Karaman Özlü Z, Eskici V, Gümüş K, Yayla A, Özlü İ, Aksoy D, Yeşilay Y. Acil Birimlerde Çalışan Hemşirelerin İletişim Becerileri ve Empati Düzeylerinin Değerlendirilmesi. Uluslararası Hakemli Hem Araş Derg (UHD) 2016;8:52-71. [CrossRef]

29. Kumcağız H, Yılmaz M, Balcı Çelik S, Aydın Avcı İ. Hemşirelerin İletişim Becerileri: Samsun İli Örneği. Dicle Tıp Derg 2011;38:49-56. [CrossRef]

30. Karadağ M, Işık O, Cankul iH, Abuhanoğlu H. Hemşirelerin İletişim Becerilerinin Değerlendirilmesi. Gazi Üniv İktisadi ve İdari Bilim Fak Derg 2015;17:160-79. Erişim: https://dergipark.org.tr/download/ article-file/287195 